\title{
Recycling spare parts
}

Citation for published version (APA):

Boeckx, W. D. (1999). Recycling spare parts. Maastricht University. https://doi.org/10.26481/spe.19991126wb

Document status and date:

Published: 26/11/1999

DOI:

10.26481/spe.19991126wb

Document Version:

Publisher's PDF, also known as Version of record

\section{Please check the document version of this publication:}

- A submitted manuscript is the version of the article upon submission and before peer-review. There can be important differences between the submitted version and the official published version of record.

People interested in the research are advised to contact the author for the final version of the publication, or visit the DOI to the publisher's website.

- The final author version and the galley proof are versions of the publication after peer review.

- The final published version features the final layout of the paper including the volume, issue and page numbers.

Link to publication

\footnotetext{
General rights rights.

- You may freely distribute the URL identifying the publication in the public portal. please follow below link for the End User Agreement:

www.umlib.nl/taverne-license

Take down policy

If you believe that this document breaches copyright please contact us at:

repository@maastrichtuniversity.nl

providing details and we will investigate your claim.
}

Copyright and moral rights for the publications made accessible in the public portal are retained by the authors and/or other copyright owners and it is a condition of accessing publications that users recognise and abide by the legal requirements associated with these

- Users may download and print one copy of any publication from the public portal for the purpose of private study or research.

- You may not further distribute the material or use it for any profit-making activity or commercial gain

If the publication is distributed under the terms of Article $25 \mathrm{fa}$ of the Dutch Copyright Act, indicated by the "Taverne" license above, 


\title{
RECYCLING SPARE PARTS
}

\author{
REDE UITGESPROKEN \\ BIJ DE AANVAARDING VAN HET AMBT VAN
}

hoOgleRAar In DE PLAstische EN RECONSTRUCTIEVE CHIRURGIE

\author{
AAN DE UNIVERSITEIT MAASTRICHT \\ OP VRIJDAG 26 NOVEMBER 1999 \\ DOOR DR. W.D. BOECKX
}



Mijnheer de Rector Magnificus,

Dames en Heren,

\section{INLEIDING}

De vraag beantwoorden:'Wat is het domein, het toepassingsgebied van plastische chirurgie' intrigeert velen. Waarvoor hebben we plastisch chirurgen nodig? Hoe kunnen ze weefseldefecten weer herstellen? In een tijdperk waar als oplossing voor vele defecten het klonen van levende wezens, zelfs de mens, aandacht krijgt in de pers en sensatie oproept in de media, zijn de ethische aspecten van het klonen echter politiek nog niet beslecht. Lichaamsdefecten herstellen gebeurt dikwijls door synthetisch vervaardigde organen en pseudoweefsels in te planten.

Biomaterialen, zelfs degradeerbare, werden in de jaren zeventig en tachtig ontwikkeld. 'Hun levensduur echter is niet onbeperkt en wint het niet, vergeleken met de originele stukken. Zeker wanneer continue wrijving en drukbelasting een grote rol spelen, zoals bij gewrichtsprothesen van heup of knie. Implantaten, biomaterialen en prothesen hebben dus hun inherente nadelen en die wensen wij te vermijden. ${ }^{2}$ Voorbeelden hiervan zijn implantaten uit lichaamsvreemde materialen, zoals endoprothesen, epithesen, metalen implantaten, acrylderivaten zoals Palacos en P.T.F.E., en vulmaterialen zoals siliconen ${ }^{3}$ en botvervangmiddelen, zoals synthetisch bot calcium hydroxieapatiet en bot-vervangmiddelen in Craniofaciale of Maxillofaciale Chirurgie."

Het zoeken naar vervangmiddelen yoor lichaamsdelen heeft recent geleid tot het gebruik van "donor materialen" zoals donor bottransplantaten ${ }^{5}$ en donor gewrichten. Allerlei weefsels, afkomstig van overleden donoren, worden gepreserveerd en bewaard voor hernieuwd gebruik bij patiënten die vervangweefsels nodig hebben. Echter, de kwaliteitscontrole ${ }^{6}$ op deze donorweefsels is niet eenvoudig. Bacteriologische besmetting kan gemeten en voorkomen worden. Virale infectie is moeilijker te detecteren en zeker te behandelen. Nochtans kumnen de gevolgen van een virale infectie zoals Aids voor de orgaanontvanger dodelijk zijn.? 
Andere overdraagbare ziekten, zoals Creutzfeldt Jacob ${ }^{8}$ met zijn moeilijk opspoorbare prionen, hebben recent de hele menselijke en vooral dierlijke weefsel donorwereld op zijn kop gezet. De 'gekke koeienziekte' in Engeland heeft de ernst van BSE (Bovine Spongiform Encephalopathy) ${ }^{9}$ in het licht gesteld en geleid tot onzekerheid over het veilig gebruik van donorweefsels. ${ }^{10}$ Alleen na de dood kan hersenonderzoek van de donor de diagnose bevestigen. Daarnaast vergt het transplanteren van levende weefsels afkomstig van menselijke donoren, het onderdrukken van het immunologisch afweersysteem."

Antibiotica hebben de bacteriële infecties significant kunnen verminderen, zoals ook de vaccins dit voor infectieziekten gedaan hebben. Vooral de infectiegevoeligheid en het verzwakken van de lichaamsbarrière voor lichaamsvreemde elementen neemt toe wanneer immunosupressiva toegediend worden. Voor levensnoodzakelijke organen zoals hart, nieren en lever wegen de voordelen van het onderdrukken van de afstotingsreactie op tegen de risico's hiervan. ${ }^{12 .}{ }^{13}$ Daarom de vraag naar betere oplossingen om zieke en aangetaste weefsels te vervangen of te herstellen, zonder risico om overdraagbare ziekten van de donor naar de patiënt over te brengen.

Daarom ons voorstel om "lichaamseigen weefsels en organen te creëren", (prefabricatie) samen te stellen, op te bouwen, om reeds bestaande bouwstenen te gebruiken ${ }^{14,15}$ of te hergebruiken voor nieuwe doeleinden, om een functionele verbetering te bereiken; dit door een opwaardering, "upgrading" van lichaamseigen bouwstenen. We stellen voor om structuren (weefsels die we in overvloed hebben), te hergebruiken om defecte lichaamsfuncties te vervangen, om nieuwe weefsels te vormen en te ontwikkelen. Door hergebruik van de bouwstenen, kunnen we economisch spaarzaam werken en een volautomatisch onderhoudscontract inbouwen.

Immers lichaamseigen weefsels krijgen automatisch een onderhoudsbeurt door celvervanging, celverjonging, celopbouw en celregeneratie. En dit zolang de patiënt blijft leven.

Het hergebruik van materialen is een doelstelling voor milieubewust grondstoffengebruik. Milieuactivisten die zich bewust 
worden van het beperkte aambod van grondstoffen op deze aarde en die de afvalberg willen beperken sporen ons aan grondstoffen te hergebruiken. $\mathrm{Zij}$ zetten ons aan het denken om zuinig om te springen met onze "lichaamsgrondstoffen". Zij sporen ons aan om na te gaan of hergebruik mogelijk en zinvol is. ${ }^{16}$

Lichaamseigen stoffen, die in tegenstelling tot "biomaterialen" en synthetische producten in het lichaam kunnen ingeplant worden en reeds in de jaren 70 en 80 ontwikkeld werden. Lichaamseigen weefsels, niet alleen om de neveneffecten en nadelen van biomaterialen zoals implantaten te beperken, maar vooral om de levensduur na de hersteloperaties, na de reconstructieoperatie, te optimalliseren.

Wanneer we nu opteren om lichaamseigen materialen, die niet levensnoodzakelijk zijn, te recycleren, dan moeten deze aan de volgende voorwaarden voldoen:

1. Er mag geen functie- of vormverlies zijn als we deze recyclageweefsels gebruiken.

2. De recyclage vervangmiddelen moeten de te herstellen weefsels, hun vorm of functie zo dicht mogelijk benaderen of zelfs verbeteren.

3. De recyclage operatie zelf mag geen nadelen, zelfs tijdelijk, berokkenen aan de patiënt, dus een minimale operatieve morbiditeit veroorzaken.

4. Het resultaat dat met recyclage onderdelen bereikt wordt, moet beter zijn dan wanneer implantaten of biomaterialen gebruikt worden. Indien dit resultaat niet verkregen kan worden, verdienen biomaterialen toch nog de voorkeur, maar dan liefst op de minst lichaamsmilieuonvriendelijke manier. 


\section{DE OPDRACHT VOOR DE PLASTISCH CHIRURG}

Hulp bieden bij het herstellen van het lichaam. Vooral wanneer andere collegae hierbij moeilijkheden ondervinden, daar het buiten hun vakgebied ligt.

Bij congenitale misvormingen, kankeroperaties, degeneratieve aandoeningen en traumata is plastische chirurgie noodzakelijk

Bij kankeroperaties, waarbij delen van het lichaam omwille van hun kwaadaardige verandering verwijderd dienen te worden, dit om het gezwel met inbegrip van zijn wortels uit te roeien en verdere uitbreiding of recidief tegen te gaan. ${ }^{17}{ }^{18}$ Hier mag de oncologische chirurg geen compromissen aanvaarden ten aanzien van de volledigheid in het verwijderen van de tumor. De plastisch chirurg kan hier voor contour- en functieherstel zorgen, in sommige gevallen met herstel van spier en zenuwfunctie.

$\mathrm{Bij}$ aangeboren afwezigheden van lichaamsdelen of defectvorming, moet de plastisch chirurg de organen en weefsels hervormen, ${ }^{19,20}$ dit meestal met speciale aandacht voor het esthetisch uitzicht ervan.

Bij ongevallen dienen we zoveel mogelijk de originele functie en vorm te herstellen. Functieherstel primeert echter op vormherstel. De reconstructieve plastische chirurg weet na te gaan welke, zij het dikwijls beperkte functie, na een trauma toch hersteld kan worden. Het beoordelen van de weefselschade, het evalueren van de nog aanwezige en beschikbare motoren voor functieverrichting, vooral bij handtraumata, laat toe dat de patiënt maximaal en efficiënt zijn resterende handfunctie gebruikt. De kennis van de anatomie is maar de voorwaarde, niet het doel op zich, om het functioneren van de overblijvende delen van de hand optimaal in te schatten en het revalidatie programma hieraan aan te passen. Hierbij dient rekening gehouden te worden met de beweeglijkheid en het tijdstip na het ongeval om de verstijving van pezen en gewrichten optimaal te beïnvloeden. Het is dikwijls een kwestie van juist met de hakken over de sloot te komen, vooraleer een bepaald functie-deficit door verstijving, vergroeiing zall ontstaan met als gevolg verder functieverlies. 
Onherstelbaar beschadigde delen kunnen soms als vervangstuk op andere plaatsen tussen geplaatst worden. Hiermee kan soms een belangrijk functieverlies voorkomen worden, dit door gewrichten, pezen, al of niet gevasculariseerd, of zenuwen te hergebruiken. In 1972 waren wij in Europa de eersten die microchirurgisch volledig geamputeerde vingers en ledematen gereimplanteerd hebben. ${ }^{21,22}$ Vanaf juni 1973 hebben wij de eerste vrije microvasculaire weefseltransplantaties verricht. ${ }^{15}$

Traumata veroorzaken soms grote defecten in de lichaamscontour met functieverlies. Een dun stukje huid (opperhuid en bovendeel van de lederhuid) transplanteren biedt hier echter geen stevige bedekking. Immers de volledige dikte van onze lichaamswand moet hersteld worden. Bouwstenen moeten tot in de diepte gebracht worden, met inbegrip van onze fundamenten. Dit omvat alle elementen zoals bot; spier, pezen, fascia, bloedvaten, zenuwen en tenslotte de huid. Fundamenteel hierbij is het behoud van een optimale bloedvoorziening, dit om de wondgenezing vlot en ongestoord te laten verlopen.

Hoe echter moeten die defecten gereconstrueerd worden? Grote figuren uit het verleden, zoals Leonardo da Vinci, ${ }^{23}$ Pieter Brueghel, ${ }^{24}$ Jeroen Bosch, ${ }^{25}$ Magritte ${ }^{26}$ of ook "De Limburgers van het azM ${ }^{* 27}$ artiesten met uitgebreide technologische verbeelding en fantasie, kunstenaars, portrettisten die in het verleden afwijkende lichaamsvormen en ziekten geportretteerd hebben, geven ons nu ideeèn ter reconstructie.

Bij mijn intrede in het AZ Maastricht, ontdekte ik de "Kunst der Limburgers". Daar had ik iets mee gemeen: hun inspiratie. " ${ }^{15}$, Een geamputeerde hand : reïmplanteren of niet? ${ }^{28,29,30}$ In zijn te groot schilderij, te groot om op én paneel geschilderd te worden, heeft Toon Teeken van zijn doek een tweeluik gemaakt, dit met amputatie van de duim tot gevolg. Later heeft de kunstenaar de twee delen weer netjes bij elkaar gebracht zodat de hand er weer normaal uitziet. Dit is ons "reimplantatie" voorbeeld. ${ }^{27}$ Zoals Carpay het in zijn voorwoord voor dit kunstboek schrijf:" The azM may well have national and international aspirations, but it has its home in Limburg, something it wishes to express. This book about Limburg artwork at 
the azM, is an attempt to do so." Als Limburger, "Limburg" included both the Belgian and the Dutch provinces of that name", kan ik mijn creatieve bijdrage leveren aan de hersteloperaties die nodig zijn in het azM.

\section{WISSELSTUKKEN RECYCLEREN}

Dit is een opgave, een opdracht voor de huidige plastisch chirurg. Het is zijn opdracht, zijn taak, met "lichaamseigen materialen" creatief te werken, nieuwe vormen te creëren, vorm te geven aan reserve onderdelen die ons lichaam "aan boord" heeft. ${ }^{16}$

Elementen die bij de mens "geen specifieke" of "geen onmisbare" functie hebben of waarvan het functie verlies opweegt tegen de winst die we verkrijgen wanneer we ze als reconstructie bouwsteen gebruiken. Onze taak: de overvloed waarmee de natuur ons voorzien heeft economisch gebruiken, spaarzaam met weefsels om te gaan om defecten te herstellen, nieuwe vormen te maken, nieuwe functies te creëren, functieverlies opnieuw te herstellen. ${ }^{31}$

Weefsels die we "in overvloed hebben" of niet onmisbaar zijn kunnen zowel huid, fascia, zenuw, bloedvaten, spier of botweefsel zijn. Overbodige huid met eigen bloedvoorziening vinden we op de romp, ${ }^{32}$ voorarm ${ }^{33}$ bovenarm of de schouderstreek en benen. Goed gevasculariseerde fascia ${ }^{34,}{ }^{35}$ zit onder de hoofdhuid verscholen. Spierweefsel kunnen we, afhankelijk van de benodigde afmeting op de rug, de buik of het bovenbeen vinden. De gracilis spier levert bij wegname geen functieverlies op. De rechte buikspier kan met weinig neveneffecten verwijderd worden, zeker wanneer maar een smal deel ervan of alleen de huidbloedvaten die er doorheen gaan, gebruikt worden.

Botweefsel kan meestal uit het kuitbeen of de heupkam genomen worden, liefst met behoud van het buitenblad van het heupbeen. Een geamputeerde neus opnieuw vormen ${ }^{36}$ met een rib, zoals de Schepper? Neen niet zo extreem als Eva "volledig geschapen" werd uit de rib van Adam, maar toch wel de rib om de onderkaak te herstellen. Zeker wanneer deze, na bestraling wegens een kwaadaardig gezwel bij een eenvoudige tandextractie, breekt en niet 
meer geneest. Beenderige genezing die wel verkregen wordt wanneer wij de bloedvoorziening van de bestraalde, gedeeltelijk dood gestraalde, onderkaak herstellen door gevasculariseerd bot, zoals rib, of beter nog met de meer bot bevattende fibula of heupkam, met hun eigen bloedvoorziening te transplanteren. De osteoblasten, de jonge beendercellen in het gezonde wisselstuk, groeien opnieuw aan en bereiken vlug beenderige genezing van de botbreuk of het defect.

Voorwaarde is dat een ervaren microchirurg, plastisch chirurg, onder de operatiemicroscoop met 25 maal vergroting de doorgankelijkheid van de millimeter kleine bloedvaten succesvol herstelt zonder dat zich postoperatief een tromboseprobleem voordoet.

Ook gelaatsverlamming kan, zelfs laattijdig na het zenuwletsel, hersteld worden door zowel de zenuw als een vervangingsspier uit het bovenbeen micro-neurovasculair over te plaatsen naar de verlamde gelaatshelft.

Bij grote dijbeengezwellen in de quadriceps spiermassa ${ }^{37} \mathrm{kan}$ de kniestrekfunctie hersteld worden door de kleine aders, slagaders en de motorzenuw van de grootste lichaamsspier uit de borstkaswand (de latissimus dorsi spier) te transplanteren naar het dijbeen.

$\mathrm{Bij}$ onderbeen traumata met ernstige weke delenschade en open fracturen, soms zelfs met onderbreking van de bloedstroom naar de voet, kan de reconstructie het best met een goede spierbedekking van het bot, de vaten en zenuwen verricht worden. ${ }^{38}$

De gracilis, de slanke dijspier of de rechte buikspier (rectus abdominis) of de latissimus dorsi kunnen hiervoor het best gebruikt worden.

In het hoofd-hals gebied, na tumorresectie, ${ }^{39,40,41,42} \mathrm{kan}$ de tongbeweeglijkheid, vorm en volume hersteld worden door de rechte buikspier bezenuwd te microtransplanteren. Na bestraling is de kans op succesvol herstel met locale weefsels moeilijk. De vascularisatie van het wondgebied verbeteren is belangrijk. ${ }^{43}$ Dit kan microchirurgisch gebeuren.

Ernstige infecties van weke delen door "vleesetende" streptococcen bacteriën of beenderen, zelfs de scalp, ${ }^{44}$ waren 
tientallen jaren lang onherstelbaar. Nu kunnen ze na vernieuwen van de wond-vascularisatie onder controle gebracht worden. Een microvasculair spier-transplantaat, na bijvoorbeeld osteomyelitis van het onderbeen, kan de infectie recidiefkans tot nul herleiden. Samenwerkend met de orthopeed, die eindelijk een zeer uitgebreide resectie van alle geïnfecteerde botsekwesters kan verrichten, hebben wij de mogelijkheid om d.m.v. de gracilisspier, die bij de mens een ideale vervangspier is, het defect te sluiten. Door de botvascularisatie te optimaliseren verbeteren we tevens het lichaamseigen afweermechanisme tegen infectie, namelijk het fagocyteren van bacteriën uit het wondbed. Immers de gracilisspier kan het gehele wondoppervlak bedekken en zelfs in de mergholte ingezogen worden. Door middel van zijn zeer uitgebreid vaatnetwerk brengen we witte bloedcellen en macrofagen in de wond, zodat die op natuurlijke wijze en continu de bacteriën opruimen die in het bot nog aanwezig zijn. Belangrijk hierbij is de kennis dat door revascularisatie van de weefsels de voeding kan verbeteren en een betere kwaliteit van wondgenezing kan verkregen worden. Specifieke aminozuren, nodig voor proteïne-herstel kunnen via de nieuwe vascularisatie de wondgenezing bevorderen. Research over het effect van zeer specifieke voedingssupplementen bij microchirurgie staat nog in de kinderschoenen, maar trekt onze belangstelling, in eerste instantie als laboratoriumprojecten.

Borsttumoren leiden dikwijls tot amputatie. Nadat bijkomende behandeling met bestraling en medicamenteuze therapie het recidief verminderd hebben, vraagt de patiënt frequent naar een hersteloperatie om haar lichaamsbeeld en kledingcomfort te verbeteren.

Vroeger waren hier uitwendige of later inwendige prothesen aangewezen. Echter lichaamseigen materialen die een natuurlijke soepelheid en beweeglijkheid hebben, geven de patiënt een beter gevoel, ${ }^{45,46,47}$ een indruk normaler te zijn, minder een gevoel van 'bijgewerkt" te zijn. Ze voelen zich beter in hun vel. Hun lichaamsbeeld, hun zelfervaring, zelfvertrouwen, hun levenskwaliteit, hun levenslust is beter. In recent onderzoek hebben we dit kunnen aantonen. ${ }^{48}$ 
Om met "eigen weefsels" een borstreconstructie te verrichten moet de plastisch chirurg beschikken over een excellente microchirurgische ervaring: microchirurgisch bestaat de mogelijkheid om het ontbrekende borstweefsel te vervangen. ${ }^{49}$

Anders dient een "spiervaatsteel" te zorgen voor het behoud van de bloedvoorziening van het weefsel. De abdominale huid, die na zwangerschappen gerelaxeerd is, bevat meestal een vetreserve, voldoende groot in volume om de afwezige borst te vervangen. Microchirurgisch wordt de vascularisatie van het buikvet en de huidmassa weer hersteld via microscopische anastomose tussen de bloedvaten van de buik en de thorax. ${ }^{50}$

Als beste keuze kiezen wij voor de bloedvaten juist achter het borstbeen, de mammaria interna. Hiervoor worden micromillimeter dunne nylon hechtingsdraden gebruikt, meestal 18 tot 40 micron dik met 70 tot 100 micron dikke hechtnaalden. In plaats van hechtingsdraden doorheen de bloedvatwand te brengen kunnen we ook fijne haakjes aan de buitenkant van de bloedvatwand plaatsen, dit om de twee wanddelen tegen elkaar te drukken. Deze bloedvat"stapling-methode" hebben we zelf geoptimaliseerd."

$\mathrm{Na}$ het verwijderen van een stukje kraakbeenrib vinden wij de borstbeenbloedvaten, de mammaria interna vaten. Indien noodzakelijk kan een hals of bovenarmader de retour bloeddrainage verzekeren via een omleggen van deze overtollige aders naar de borststreek toe. Met behulp van de operatiemicroscoop worden deze vaten, onder 25 maal vergroting met een tiental hechtingen bij elkaar gebracht. De anastomose moet onmiddellijk waterdicht zijn om lekkage met stolselvorming en trombosevorming te voorkomen. Ter hoogte van de borst kunnen de vaten eindstandig aan elkaar gehecht worden. Vervangweefsel op afstand transplanteren omvat echter een korte periode waarin de bloedcirculatie volledig onderbroken wordt.

Regelmatige controle van de microvaatanastomose is steeds nodig. De eerste vijf dagen na de operatie dient zeer frequent de bloedstroom door de microvaatsutuur geobjectiveerd te worden, dit met ulltrasone flowmetingen. Bij occlusieneiging biedt een snelle reïnterventie de enige mogelijkheid om, vooraleer de weefsels afsterven, de circulatie weer te herstellen en de weefseloverleving te 
verbeteren. Dit vergt een team approach, immers de zwakste schakel in het behandelingsteam bepaalt het eindresultaat. De verpleegkundigen, die dag en nacht aanwezig zijn, verrichten de follow-up. Hun ervaring is van cruciaal belang om vroegtijdig (voor het kalf verdronken is) de problemen te ontdekken en op te lossen, dit in overleg met de chirurg. Belangrijk hierbij is onze ervaring in het evalueren van de receptorvaten, vooral wanneer deze door radiotherapie beschadigd zijn. Experimenteel de flowrichting bestuderen waarbij de bloedstroom zich optimaal in een vrije lap begeeft, leert ons hoe we klinisch de receptorvaten moeten selecteren en positioneren en in welke volgorde de belangrijke stappen van de microsutuur dienen verricht te worden.

Vroeger kon weefselherstel verricht worden wanneer in de buurt van het weefseldefect zelf de juiste vervangmiddelen beschikbaar waren. Dan kon met behoud van de eigen bloedvaten, het vervangweefsel naar het defect gebracht worden. Dit werd toegepast wanneer bijvoorbeeld in een hand een weefseltekort aangevuld moest worden. Bij de ziekte van Dupuytren wordt het zieke weefsel verwijderd en wordt meestal uit de nabije omgeving via zigzag insneden ( $Z$ plastiek) weefsel gevonden om het defect te bedekken. $B i j$ recidief kan deze locale flapreconstructie niet meer mogelijk zijn. Het weefseltekort dat ontstaan is kan hersteld worden door van op afstand een microchirurgische 'veneuze flap' te gebruiken. Hierbij, zij het slechts voor beperkte defecten, vooral in de hand, is het niet nodig een majeure lichaamsarterie op te offeren, maar alleen de oppervlakkige onderhuidse aders te gebruiken. De microcirculatie in de lap wordt op een ongewone, retrograde wijze gevuld om weefselperfusie te bekomen. $\mathrm{Na}$ enkele weken is de toestand weer gestabiliseerd door bloedvat nieuwvorming of angiogenese. Het donordefect van de lap is minimaal. Geen arterie werd beschadigd.

In 1973 heb ik samen met A. de Coninck van de Katholieke Universiteit te Leuven de eerste microchirurgische flaptransplantatie in Europa verricht. ${ }^{15}$ Deze operatie verrichtten wij slechts enkele maanden nadat ze een eerste maal ter wereld door Rolin Daniel en Ian Taylor in Melbourne uitgevonden werd in de research afdeling van Bernard O' Brien. 
Hier hebben we later een deel van onze opleiding doorgemaakt.

Nadien hebben we de microchirurgie verder ontwikkeld in andere toepassingsgebieden zoals de gynaecologie ${ }^{52,53}$ en urologie ${ }^{54} \mathrm{We}$ hebben eileiders na sterilisatie weer aan elkaar gehecht, hydrosalpinges microchirurgisch weer geopend en ovariële endometriose verwijderd.

Experimenteel werk hierover in mijn proefschrift toonde aan welke guidelines wij hierbij dienden te volgen. We hebben de niet ingedaalde testis van de cryptorchidiepatiënt microchirurgisch getransplanteerd naar de balzak ${ }^{57}$ en bij arteriële vasculaire impotentie werd de penis gerevasculariseerd. Vooraleer de microvasculaire chirurgie klinisch toe te passen hebben we jarenlang experimenteel op ratten de microvasculaire basisprincipes ontwikkeld $^{58}$ en de transplantimmunologie van harttransplantaties, ${ }^{12}$ ovaria transplantaties $^{59}$ en niertransplantaties bestudeerd.

Typisch voor de chirurgische basisresearch is het ontwerpen van nieuwe operatietechnieken ${ }^{60}$ en het ontwikkelen van nieuwe weefsels die we als bouwsteen kunnen gebruiken. ${ }^{61}$

De anatomie van nieuwe flappen trok initieel onze aandacht zoals de axillaire huidflap. ${ }^{16}$

Ook hebben we experimenteel de criteria vastgelegd waaraan een microanastomose moet voldoen ${ }^{62,63,64,65,66,67,68,69,70,71}$ en nagegaan hoeveel training vereist is en welke kwaliteitscriteria moeten bereikt worden in labo omstandigheden vooraleer men de confrontatie met de patiênt mag aangaan. De klinische studie van beschadigde bloedvaten na radiotherapie leert ons criteria opstellen waaraan een microvasculaire anastomose moet voldoen in deze specifieke moeilijke situatie. ${ }^{66,71}$

\section{DE BEGEESTERING VOOR HET VAK DOORGEVEN AAN DE JONGEREN}

Nochtans als plastisch chirurg moeten we onze limieten kennen. Wij moeten weten hoe ver weefsels verplaatst kunnen worden zonder dat hun vascularisatie in het gedrang gebracht wordi. Wij moeten weten hoe bepaalde incisies in de huid en dieper gelegen weefsel, later, na verplaatsing of transpositie, nog gesloten kunnen 
worden. Wij moeten 'futuristisch" en 'drie- dimensioneel' denken. Denken aan de toekomst, aan het verdere verloop van de operatie. Ons afvragen hoe, na verplaatsing van de weefsels, de vorm en functie van het nieuw gevormde orgaan er zal uitzien.

Het 'plan' vooraf op de huid van de patiënt zelf uittekenen is zeer zinvol. Kijk maar naar Leonardo da Vinci en Michel Angelo die ons dit in de $15 \mathrm{e}$ en $16 \mathrm{e}$ eeuw reeds hebben getoond. Wij leren uit ons verleden, van de meester-op-leerling. Als opleiders moeten wij daarom aan de jongeren, de assistenten-in-opleiding, onze ervaring doorgeven. Ook het enthousiasme, de begeestering die we voor ons vakgebied hebben, moeten we doorgeven. Wij moeten aan de jongeren leren dat uit enkele basistechnieken, "basisrecepten" voor elke individuele patiënt een aangepaste oplossing, een adequaat behandelingsplan kan opgesteld worden.

Protocollen kunnen hierbij behulpzaam zijn. Protocollen echter mogen niet 'as such' toegepast worden, niet zonder na te denken, niet zonder aan de specifieke behoeften van de actuele patiënt te denken. Hierdoor overstijgt het actuele behandelingsplan de waarde van een basisprotocol. Het individuele operatieplan moet een meerwaarde hebben, meer bieden dan de basisideeën van het protocol. Daarom mag een protocol nooit beschouwd worden als een richtlijn die toegepast moet worden, om conformiteit te bekomen. In de plastische chirurgie mag 'het protocol' niet belemmeren de creativiteit, de 'plasticiteit" op te drijven tot op grote hoogte. Mijn vroegere leermeesters drongen er steeds weer op aan om dan pas een operatie aan te vatten, wanneer we drie oplossingen voor het actuele probleem hadden kunnen bedenken: een 'ideaal' plan, een 'goed' plan en een "noodplan" om bij tegenspoed uit te voeren. In het Mount Vernon Hospital bij Londen, leerde Mister Dawson ons zo te denken. Slechts met een 'noodplan' op zak kon de operatie aangevat worden, dit nadat alles zorgvuldig vooraf gepland was. Liefst met de pen en inkt, de tekenpen in de hand, om op de huid van de patiënt zelf het plan uit te tekenen. Dit gaf ons meer inzicht, meer overzicht, meer visie op het uiteindelijk resultaat van de reconstructie met aandacht voor de begeleidende gevolgen. Slechts wanneer we een "ideaal" plan hadden, een verbeterde versie van het "goede" plan, een versie 
die herdacht, bijgewerkt en geoptimaliseerd was, rekening houdend met de 'pitfalls', de 'adders onder het gras. Een plan met 'begeestering', met een 'ziel' om beter te doen, om iets extra te bieden, beter zelfs dan "the gold standard". Deze, meer dan "gemiddelde oplossing" moeten wij als gedachtegoed meegeven aan de assistenten die wij opleiden. Door de 'tekening van ons plan' op de huid en weefsels van de patiënt te maken, tonen wij hoe we over het probleem nagedacht hebben. Tonen we de conclusie van onze analyse van het probleem, stellen we het open voor verder overleg en discussie onder collegae, assistenten en stafleden. Dit natuurlijk in afweging met literatuur en recente congresbevindingen. Ook de grote bouwmeesters of schilders uit het verleden hebben steeds eerst schetsen, plannen ontworpen vooraleer hun prachtig kunstwerk te realiseren.

Een 'goede ' en een 'heel goede' oplossing is voor ons dikwijls een 'microchirurgische'. Daarom moeten we bij een kankerreconstructie de resectiewond niet uitbreiden, om in de buurt van het defect weefsel te zoeken waarmede we het defect kunnen sluiten. Echter, wel op afstand van de tumor, om uitzaaien van tumorcellen tijdens de reconstructie te vermijden. Hierdoor kan met 'niet-gecontamineerd ' materiaal de flapdonorplaats gesloten worden. Ook uitbreiding van infectie wordt zo beperkt.

Nadenken, plannen, methoden ter reconstructie met elkaar afwegen, enthousiasme doorgeven aan de jongeren, jongeren die zo frequent mogelijk betrokken dienen te worden, zowel bij de planning als de uitvoering van de reconstructies.

Assistenten in opleiding moeten bij alle fasen van diagnose en behandeling betrokken zijn: de preoperatieve diagnosestelling, het selecteren van de juiste indicatie voor de operatietechniek die toepasbaar is en voor elke genomen operatiekeuze de gevolgen en de risico's ervaren, het inschatten van de complicaties en de omstandigheden evalueren om een welbepalde behandelingsmethode te verkiezen. Het herhaaldelijk afwegen van voor- en nadelen van de verschillende operatieve mogelijkheden is het moeilijkst om aan te leren en staat niet in de boeken. Met de tientallen jaren opgedane ervaring kunnen we raad geven om de 
verschillende factoren die de beste keuze helpen maken, af te wegen, met een visie op de uiteindelijke resultaten en rekening houdend met de donormorbiditeit. Alleen door toekomstvisie te ontwikkelen, gebaseerd op multifactoriële analyse van het probleem, de oplossing en de consequenties, kan voldoende klinische ervaring ontwikkeld worden.

Parallel hieraan moeten via experimenteel onderzoek de fundamentele mechanismen onderzocht en ontleed worden om ons klinisch denken te beînvloeden en optimaliseren. Wanneer we met de rug tegen de muur staan, of toevallig een gunstige klinische ervaring opdoen, dan moeten we kritisch en analytisch te werk gaan. Door de puzzel niet in zijn geheel, maar stap voor stap, niet zozeer op te lossen, maar in zijn bouwstenen uiteen te rafelen, te vereenvoudigen, om dan stapsgewijze de mechanismen te analyseren die ons helpen na te denken over de klinische problemen. Door nieuwe bouwstenen te ontwikkelen, nieuwe wisselstukken te ontdekken, nieuwe structuren te creëren, door weefsel nieuwvorming, door neovascularisatie, neo-angiogenese, weefselinductie, manipuleren van inflammatie en weefselgroeistimulatie; indien nodig met groeifactoren en farmacologische nutriënten of genetische manipulatie. Deze nieuw benoemde, ontdekte, geproduceerde of geînduceerde weefsels vormen dan de nieuwe "wisselstukken" waarover we in de toekomst kunnen beschikken. Waarschijnlijk dan met meer aandacht voor 'ecologie', voor donormorbiditeit zullen we er in slagen 'prefabricatie' te doen van specifieke bouwstenen, om nieuwe oplossingen te bedenken, om meer complexe defecten te bedekken, om een beter functie herstel te krijgen, bijvoorbeeld door het vooraf 'in droogdok' produceren van de vorm en samenstelling van weefsels die na tumorresectie nodig zijn om het defect te sluiten.

De laatste dertig jaren is de huidflapanatomie volledig in kaart gebracht; nieuwe donorplaatsen worden niet meer ontdekt. De inzichten in de intra-flap anatomie leiden tot steeds verdere miniaturisatie van de plaats en diameter van de vaatanastomose. Om nog verder te gaan in de miniaturisering van anastomoseerbare vaten moeten we de fysiologie van het vaatbed in de weefsels bestuderen 
en nagaan hoe de zuurstofafgave gebeurt. De fysiologie van de microcirculatie begrijpen, helpt ons om af te stappen van het gekende weefselperfusiepatroon waarbij een toevoerende arterie en afvoerende ader nodig en onmisbaar zijn. Experimenteel ontrafelen van de voorwaarden, nodig om weefseloverleving mogelijk te maken, zonder het normale arterio-veneuze netwerk in zijn globaliteit te gebruiken.

Experimenteel onderzoek zal ons ook een beter inzicht geven in de fysiologie en fysiopathologie van wondgenezing, vooral bij patiënten met marginale wondgenezingscapaciteiten zoals Aids en diabetes en arteriosclerose patiënten of immuumgecompromiteerden. We zullen bij bepaalde letsels of traumata "eenvoudigere" oplossingen of snellere herstelfasen krijgen. De research moet naar de basis gaan. Als klinisch plastisch chirurgen echter niet de fysiologie op zich te begrijpen, maar om "toegepaste research" te verrichten. Wij hebben hoogte van de klinische probleemstelling, wij weten 'wat' opgelost moet worden.

De multidisciplinaire samenwerking met basiswetenschappers, fysiologen, biochemici, pathologen zal vruchtbaar zijn zolang wij het klinisch probleem verder uitrafelen en het dynamisme, de begeestering bewaren die we, steunend op onze long term resultaten, nodig hebben om verder te zoeken naar betere oplossingen.

\section{WACHTLIJST EN ZORGFINANCIERING:}

Onze plastisch chirurgische ervaring, een oplossing bieden voor elk individueel probleem, bouwend met nieuwe of nieuwgevormde wisselstukken, moeten we regelmatig kenbaar maken aan de zorgverzekeraars. Immers zij weten niet wat onze moderne reconstructieve mogelijkheden $\mathrm{Zijn}$. Zij weten niet welke graad van functieverbetering wij kunnen verkrijgen, bijvoorbeeld na een zenuwletsel, waarbij wij een interfasciculair herstel met 18 micron dikke hechtingen verricht hebben en in $90 \%$ van de patiënten sensibele en motorische recuperatie bekomen na primaire microchirurgische hechting. $\mathrm{Zij}$ moeten ons hiervoor 'toelating geven', het 'budget' geven. 
Maar waarom zouden zij 'plastische chirurgie' toestaan? Is dit "esthetische chirurgie" dus niet verzekerde zorg? Waarom vergoeden als er geen resultaat verwacht kan worden, of toch? Wij horen: "hun budget is beperkt". Waarom? Omdat hen het inzicht ontbreekt dat nieuwe middelen, zelfs 'duurdere' operaties beschikbaar zijn, uitgevonden worden, om de levenskwaliteit, de overlevingskwaliteit, de kwaliteit van leven na de ziekte te verbeteren. Indien zij hiervan op de hoogte zouden zijn, zou het budget voor bepaalde reconstructies verhoogd kunnen worden, zoals bij de genetisch geconditioneerde kans op kwaadaardig borstgezwel en dan zouden wachtlijsten "uit den boze" zijn.

Immers een wachtlijst is, om welke reden dan ook, uitstel van executie, uitstel van uitvoering, uitstel van behandelen, uitstel om beter te leven nadat het goede resultaat van de behandeling bereikt is. Ik spreek natuurlijk alleen over de chirurgische, plastisch chirurgische behandeling. Uitstel van behandeling, het verder laten groeien van het kwaadaardig gezwel en verslechteren van de prognose, dat is de consequentie van een wachtlijst, wachttijd. Wachtlijst is in vele buurlanden een totaal onbestaand begrip, in andere landen een verdoezeling, verbergen dat er een geneeskunde met twee snelheden bestaat. Bijvoorbeeld de privé-geneeskunde in de UK, met snelle privé behandeling, die door de artsen zelf bevorderd wordt, door in het officiële circuit artificieel een wachtlijst te creëren.

De wachtlijst- problematiek kan op twee punten aangepakt worden:

De jaarlijkse toename van wachtende patiènten moet structureel aangepakt worden door nia te gaan waarom, met de voorhanden zijnde middelen, geen behandeling wordt aangeboden. Dit kan zijn gebrek aan planning of onvoldoende werknemers opleiden en voldoende salarièren om kandidaat gezondheidswetenschappers aan te trekken.

Indien het grootste deel van de wachtlijst van jaar tot jaar constant blijft, kan, door tijdelijk wegwerken van de wachtlijst, in combinatie met het bijsturen van de wachtlijstaangroei, een verbetering ontstaan. 
Dit natuurlijk samen met een verbeterde motivatie on geen wachtlijst te tolereren. Een goed hulpmiddel hierbij is in aanwezigheid van de patiënt het engagement aan te gaan hem op een welbepaald tijdstip in de nabije toekomst te behandelen. Op die wijze dwingt de arts zichzelf en zijn logistiek team om zijn taak "het behandelen van de patiënt" uit te voeren. Ook de patiënt wordt dan op de concrete realiteit gewezen dat hij op die welbepaalde dag beschikbaar moet zijn om behandeld te worden. Anders zullen allerlei secundaire argumenten door beide partijen ingeroepen kunnen worden om de operatieplanning niet te volgen. Alleen de interessante ingrepen zullen uitgevoerd worden, de anderen, zogezegd omwille van de wachtlijst, niet. Dit verhoogt de kostprijs om uiteindelijk de patiënt met een verder gevorderde ziekte nog te behandelen. Hierdoor ontstaat defaitisme en legt men zich neer bij het feit dat er een wachtlijstproblematiek bestaat. Vanaf maart 1998 zijn wij nog steeds in staat de patiënten binnen een termijn van drie maanden te opereren. Dit vergt continue inzet. Die halen we uit de analyse van het probleem of de ziekte van de patiënt, dit met al zijn emotionele, psychologische, fysische, oncologische en functionele implicaties. Het heeft geen zin een revalidatiecentrum in te schakelen, indien we er niet in geslaagd zijn de patiènt vroegtijdig te behandelen, vooraleer het functieverlies te ernstig wordt. Het is zinloos een patiënt te vragen zich voor niet levensbedreigende aandoeningen op de polikliniek aan te bieden als we weten dat de behandeling pas kan volgen wanneer de huidige gegevens onbetrouwbaar of waardeloos geworden zijn of op zijn minst "out dated". Ook laat dit niet toe een preoperatieve screening op te zetten, de feiten zullen achterhaald zijn op het ogenblik van de behandeling. Dus de patiënt moet centraal staan en niet de planning, de opnameplanning, de OK-planning, de beddenplanning. Alleen door kort op de bal te spelen, door een strikt interval tussen polibezoek en operatietijdstip te behouden, zal de patiënt tijdig behandeld worden en maximaal voordeel halen uit zijn operatic. Als het kalf verdronken is, als de ziekte verergerd is, kan zelfs de meest recente en gesofisticeerde therapie niet het optimale resull taat leveren. In de plastische chirurgie dreigt nog het risico dat onvoldoende 
financiering voor de verzekerde zorg aanleiding geeft om extra tijd te besteden aan de overdreven lucratieve niet-verzekerde zorg, zoals de louter esthetische operaties. Ook hier zullen de jongeren moeilijk de verleiding weerstaan om "esthetische chirurgie" in privé klinieken te verstrekken ten nadele van de reconstructieve chirurgie bij kanker, trauma en congenitale aandoeningen. Alleen een juist evenwicht tussen beiden, met een billijke en stimulerende financiële vergoeding voor de inspanning, het initiatief, het werk, vooral het microchirurgische werk, biedt garanties dat het enthousiasme voor het reconstructieve werk behouden blijft. Dit is noodzakelijk om het "esthetische" geen voorrang te laten krijgen onder het mom van " de wachtlijst". Wanneer zowel het hotel (ziekenhuis) als het bedrijf (operatiekamer), maar ook de werknemer (academische specialist) zich in een financieel gunstig klimaat bevinden dan kunnen wij ons enthousiast verdiepen in de probleemanalyse van de reconstructie bij de individuele patiènt. Dan gaan we in de microchirurgische of andere trukendoos op zoek om de juiste, zo niet onmisbare vervangstukken te vinden die we kunnen recycleren. Dan kan de oncologisch chirurg, de traumatoloog, vaatchirurg, gynaecoloog, dermatoloog, $\mathrm{KNO}$-arts, kaakchirurg ervaren dat de plastisch chirurg klaar staat om de eindafwerking van de operatie te verrichten. Bij het herstellen van de defecten, bij de wederopbouw van het lichaam zal de plastisch chirurg vakkundig, met zin voor architectuur, vorm, schoonheid en functie, rekening houden. Dit met efficiënt en inventief gebruik van zoveel mogelijk herbruikbare wisselstukken. Hier ligt ons werkterrein. 


\section{REFERENTIES}

1. Knahr K, Salzer M, Plenk H Jr, Grundschober F, Ramach W. Biomaterials 1981; 2: 98-104.

2. Athanasiou KA, Niederaurer GG, Agrawal CM. Steriliztion, toxicity, biocompatibility and clinical applications of polyactic acid / polyglycolic acid copolymers.

Biomaterials $1996 ; 17: 93-102$

3. Van Noort R, Black MM. Silicone rubbers for medical applications.

In Williams, D.F. (Ed.): Biocompatibility of Clinical Implants. Materials. Voll II. Boca Raton, CRC Press 1981.

4. Van Raemdonck, Ducheyne, De Meester.

In Ducheyne P and Hastings GW (Eds. ) Metal and Ceramic Biomaterials. Vol IJ. Boca Raton, CRC Press, 1984.

5. Cohen J. Biomaterials in orthopedic surgery. Am J. Surg, 1967; 114: 31-41.

6. Hirn MY, Krusius T. Retesting of bone donors 2 months after donation guarantees sufficient safety of bone allografts. Acta Orthop Scand 1998; 69: 559-566.

7. Denner J. Immunosuppression by retroviruses: implications for xenotransplantation.

Ann N_Y_ Acad Sci . 1998; 862: 75-86.

8. Tan L, Williams MA, Khan MK, Champion HC, Nielsen NHN. Risk of transmission of bovine spongiform encephalopathy to humans in the United States: report of the Council on Scientific Affairs.

American Medical Association. JAMA 1999; 281: 2330-2339. 
9. Mastrianni JA. The prion diseases: Creutzfeldt-Jacob, GerstmanStraussler- Scheinker, and related disorders.

J. Geratr Psychiatr Neurol 1998; 11: 78-97.

10. Moor AC, Dubbelman TM, Van Steveeninck J, Brand A. Transfusion- transmitted diseases: risks, prevention and perspectives.

Eur. J. Haematoll. 1999; 62: 1- 18.

11. Boeckx W, Van de Maele B, Sobis H, Vandeputte $M$. Harttransplantatie bij cle rat als model tot studie van de transplantatie immuniteit.

Acta Clin Belg, 1975; 30/02: 90.

12. Boeckx W, Sobis H, Lacquet A, Gruwez J, Vandeputte M. Prolongation of allogeneicheart graft survival in the rat after implantation on portal vein.

Transplantation, 1975; 19: 145-149.

13. Boeckx W. Heart Transplantation.

Microsurgery, 1976; 4: 75-96.

14. De Coninck A, Vanderlinden E, Boeckx W. The thoracodorsal skin flap: A possible donor site in distant transfer of island flaps by microvascular anastomosis.

Chir Plastica (Berlin), 1976; 3: 283-291.

15. Boeckx W, De Coninck A, Vanderlinden E. Ten free flap transfers : the use of intra-arterial dye injection to outline a flap exactly.

Plast Reconstr Surg, 1976; 57/06: 716-721.

16. De Coninck A, Boeckx W, Vanderlinden E, Claessen G. Autotransplants avec microsutures vasculaires. Anatomie des zones donneuses.

Ann Chir Plast, 1975; 20/02: 163-170. 
17. Boeckx W. Les transplants libres. Reconstruction du talon sur radiolesion.

Lettre d'information GAM 1975; 2: 1-10.

18. Boeckx W, De Coninck A. Vrije gevasculariseerde huidflap transplantaties en vingerreïmplantaties.

Biotechniek, 1975; 85-89.

19. Boeckx W. Atrofie van het gelaat - Majeure indicatie voor een vrije gevasculariseerde subcutane vettransplantatie.

Microchirurgie, 1976; 2: 12-14.

20. Boeckx W. Clinical Micro-Surgery.

In : Micro-surgery: Experimental techniques in the rat and clinical applications, 1976; 183-235. Eds. :Marquet R, Hess F, Kort W, Boeckx W. European Press Gent, Belgium.

21. Gruwez J, Boeckx W, Duponselle E. Reimplantatie van extremiteiten.

Tijdschr Geneeskunde 1973; 21: 1023-1026.

22. Boeckx W, Gruwez JA, Lacquet A. Vingerreimplantatie. Acta Chir Belg, 1975; 74/5: 521-530.

23. L. da Vinci, Reti L e.d. Spectrum Antwerpen 1974; 123-125.

24. Brueghel P. Clefs d'óeuvre de l'árt. Grand Peintres. Ed: Hachette Paris. 1996; 1 - 9.

25. Bosch $\mathrm{H}$.

In: De Vlaamse Primitieven. C. Vindis limentani. Ed: Davidsfonds, Leuven. 1994; 437 - 459 .

26. Margritte, Sylvester D.

Ed: Mercatorfonds, Antwerpen. 1992; 125 - 195. 
27. De Limburgers van het azM.

Limburg artists at the azM, Carpay et.al, Maastricht 1998.

28. Boeckx W, Demey R, Guelinckx P, Dewilde R, Gruwez JA Results of microsurgical fingerreimplantations.

Acta Orthop Belg, 1981; 47/06: 788-797.

29. Boeckx W, Demey R, Guelinckx P, Dewilde R. Ervaring met vingerreimplantaties sedert 1972.

Acta Chir Belg 1982; 3: 191-198.

30. Boeckx W, Jacobs W, Guelinckx P, Van de Kerckhove E. Late results in replanted digits. Is replantation of a single digit worthwhile?

Acta Chir.Belg, 1992; 92: 204-208.

31. Boeckx W, Guelinckx P, Brosens I, Gruwez JA. Microchirurgie in 1982. Plaats van de techniek in de verscheidene heelkundige disciplines. Opleidingsmogelijkheden en voorwaarden voor jonge chirurgen.

Acta Chir Belg, 1982; 3: 151-160.

32. De Coninck A, Vanderlinden E, Boeckx W. The thoracodorsal skin flap:A possible donor site in distant transfer of island flaps by microvascular anastomosis.

Chir Plastica (Berlin) 1976; 3: 283.

33. Delaere PR, Boeckx WD, Ostyn F, Tyberghein J, Guelinckx PJ. Hypopharyngeal stenosis and fistulas. Use of the Radial Forearm Flap.

Arch Otolaryngol Head Neck Surg, 1988; 114/11: 1326-1329.

34. Delaere P, Boeckx W, Ostyn F, Tyberghein J, Guelinckx P. Vascularized fasciocutaneous flap for reconstruction of the hypopharynx.

Acta Otorhinolaryng Belg, 1988; 42: 557-563. 
35. Guelinckx PJ, Boeckx WD, Fossion E. The unlimited possibilities of free microvascular tissue transfers in Head and Neck Reconstruction.

In : Wissenschaftliche Zeitschrift, 1988; 37: 409-418. Eds.:Friedrich-Schiller-Universitdt, Jena.

36. Boeckx W, Fossion E, Guelinckx P, Demey RI, Dewilde R. Free flaps in head and neck surgery.

Acta Chir Belg 1982; 3: 219-229.

37. Boeckx W, Guelinckx P, De Wever T, Gruwez J. Reconstruction of the quadriceps muscle in a young male patient: A case report. In Proc.2nd Vienna Muscle Symposium, 1985; 288-303. Eds. Frey M, Freilinger G, Facultas Universitätsverlag, Vienna

38. Boeckx W, Blondeel Ph, Van Raemdonck D, Broos P, Rommens $P$. The use of free flaps in the treatment of severe lower leg trauma.

Eur J Plast Surg, 1992; 15: 63-68.

39. Delaere PR, Ostyn F, Boeckx WD, Hypopharyngeal reconstruction with the radial forearm flap.

Acta Chir Belg, 1990; 90/03: 132-135.

40. Harrison DH, Morgan BDG, Boeckx W. Reconstruction of the nose : tribulations.

In : Symposium on Clinical Frontiers in Reconstr.Microsurgery 1984; 24: 132-137. Eds. : Buncke HJ, Furnas DW, The C.V. Mosby Company, St. Louis.

41. Ioannides C, Fossion E, Boeckx W. Serratus anterior muscle in composite head and neck flaps.

Head \& Neck, 1992; 177-182. 
42. Mommaerts MY, Van Hemelen G, Fossion $\mathbb{E}$, Boeckx W. Wiederherstellung in bestrahlten Oropharynx : muskulokutaner Pectoralis-major-Insellapen versus mikroanastomosierter Latissimus-dorsi-Lappen.

In : Forschritte der Kiefer- und Gesichts-Chirurgie,ein Jahrbuch.Band XXXV, Mikrochirurgie in der Mund-, Kiefer und Gesichtschirurgie, 1990; 50-52.

Eds.: Schuchardt K, Schwenzer N, Pfeifer G, Thieme G. Verlag Stuttgart, New York.

43. Ioannides Ch, Fossion E, Boeckx W, Hermans B, Jacobs D. Surgical management of the osteoradionecrotic mandible with free vascularised composite flaps.

J. Cranio-Maxillo-Facial Surgery, 1994; 22: 330-334.

44. Fossion E, Boeckx W, Jacobs D, Ioannides C, Vrielinck L. La reconstruction microchirurgicale de la mandibule irradiée par le larnbeau circonflexe iliaque profond.

Ann Chir Plast Esth, 1992; 37/3: 246-251.

45. Boeckx W, Bogaerts F.Borstreconstructie na mastectomie: actuele chirurgische mogelijkheden.

V.V.R.O. Oncologisch Tijdschrift 1990; 3: 119-122.

46. Boeckx W, Bogaerts F. Plastic Surgery and Body Image. In : Advanced Psychosomatic Research in Obstetrics and Gynecology, 1991; 43-47.

Eds. Richter D, Bitzer J, Nijs P, Springer-Verlag Berlin.

47. Bogaerts F, Boeckx W, Nijs P. Breast Reconstruction and Body Image: Psychotherapeutic Aspects.

In : Advanced Psychosomatic Research in Obstetrics and Gynecology, 1991; 48-55.

Eds. Richter D, Bitzer J, Nijs P, Springer-Verlag Berlin. 
48. Bogaerts F, Boeckx W. Brustoperationen: Warum der Chirurg den Sexuologen braucht?

Sexualmedizin, 1988; 17/05: 245-258.

49. Banic A, Boeckx W, Guelinckx P, Marchi A, Rigotti G, Tschopp H. Late results of Breast Reconstruction with Free Tram Flaps: A Prospective Multicentric Study.

Plast Rec Surg, 1995; 95/7: 1195-1204.

50. Blondeel $\mathrm{Ph}$, Boeckx W. Refinements in free flap breast reconstruction: the free bilateral deep inferior epigastric perforator flap anastomosed to the internal mammary arteeryr. Brit.J.Plast.Surg, 1994; 47: 495-501.

51. Boeckx W. Scanning electron microscopic analysis of the stapled microvascular anastomosis in the rabbit.

Ann Thorac Surg, 1997; 63:128-134.

52. Boeckx W, Vasquez G, Brosens I. Reversibility of tubal ring sterilization.

Contraception 1977; 15/05: 505-512.

53. Brosens I, Boeckx W, Gordts S. Conservative surgery of ovarian endometriosis in infertility.

Europ J Obstet Gynec Reprod Biol, 1978; 08/05: 277-279.

54. Gordts S, Boeckx W, Brosens I. Microsurgical anastomosis of the vas deferens.

Fertil Steril, 1980; 690-691.

55. Boeckx W, Brosens I, Gordts S. Microsurgical treatment of ovarian endometriosis.

Fertil Steril, 1980; 611-612. 
56. Koninckx PR, Beck WD, Verhoeven HC, Winston RML, Brosens I. Impairment of ovarian ovulatory function after tubal surgery in the rabbit.

Infertility $1980 ; 3 / 01 ; 85-90$.

57. Boeckx W, Vereecken R, Depuydt K. Microsurgery for intraabdominal testicular retention.

Eur J Obstet Gynecol Reprod Biol, 1998; 81: 191 - 196.

58. DeWilde R, Boeckx W, Van der Schueren E, Guelinckx P, Gruwez JA. A scanning electron microscopic study of microvascular anastomoses on irradiated vessels Short-term effect of irradiation.

Micro-surgery, 1983; 04/03: 193-200.

59. Denjean R, Boeckx W, Hedon B. Techniques de microchirurgie vasculaire et gynecologie.

J Gynecol Obst Biol Reprod (Paris), 1981; 10/01: 13-20.

60. Delaere PR, Guelinckx PJ, Ostyn F, Beck WD, Seghers A. Possibilities in hypopharyngeal reconstruction-comparative study.

Acta Otolaryngol Belg, 1990; 44/01: 51-54.

61. Delaere PR, Boeckx WD, Guelinckx PJ, Van de Vandevoorde WV. Laryngoplasty with vascularised and non-vascularised auricular mucochondral grafts. An experimental study in rabbits. ORL J Otorhinolaryngol Relat Spec, 1990; 52/05: 303-310.

62. Boeckx WD, Vijay Haribhakti VV, Bosmans L, Gruwez JA. End to side anastomosis of rat carotid artery : comparison of different types of section and shape of the terminal end.

Eur J Plast Surg, 1992; 15/3: 127-132. 
63. Boeckx W, Stockmans F, Guelinckx P. Tissucol in peripheral nerve repair an experimentalstudy in the rat.

In : Plastic Surgery, Nerve Repair, Burns, 1995; 43-50.

Eds. : Schlag G, Holle J, Springer-Verlag, Berlin, Heidelberg, New-York.

64. Guelinckx P, Dom R, Bex M, Boeckx W, Gruwez JA. Rectus femoris muscle grafts performed with and without vascular anastomosis. An experimental study in the rabbit.

Br J Plast Surg, 1984; 37/04: 584-595.

65. Boeckx W. Advances in experimental microsurgical anastomoses techniques and their clinical applications.

In : Verhandelingen van de Koninklijke Academie voor Geneeskunde van België, XL, 1978; 1-2: 5-129. Eds. : Paleis der Academiën, Hertogstraat 1, 1000 Brussel.

66. Boeckx W, Haribhakti VV, Bosmans L. Scanning electron microscopic study of thrombus formation in an end-to-side anastomosis of the rat carotid artery.

J. Reconstr. Microsurgery, 1994;.10/01: 35-38.

67. Guelinckx PJ, Boeckx WD, Dom R, Gruwez JA. Nerve fiber planimetry in acute and chronic nerve lesions and in nerve lesions in continuity.

Plast Reconstr Surg, 1985; 76/04: 499-509.

68. Decleer W, Vanhove M, Coenen L, Boeckx W, Gruwez JA. Fibrinous tissue glue in artery anastomosis. Physiological, histological and scanning evaluation.

Acta Chir Belg, 1985; 85/02: 121-124. 
69. Stockmans F, Guelinckx P, Boeckx W. Histological and physiological evaluation of nerve repair with microsuturing versus tissue adhesie.

Peripheral Nerve Repair and Regeneration, 1986; 3: 81-88.

70. Oelsner G, Boeckx W, Brosens I. Quality control experiment. The effect of microsurgical training on the anastomosis in the rabbit fallopian tube.

Fertil Steril, 1980; 589-590.

71. Guelinckx PJ, Boeckx WD, Fossion E, Gruwez JA. Scanning electron microscopy of irradiated recipient blood vessels in head and neck free flap.

Plast Reconstr Surg, 1984; 74/02: 217-226. 